Click www.researchjournal.co.in/online/subdetail.html to purchase.

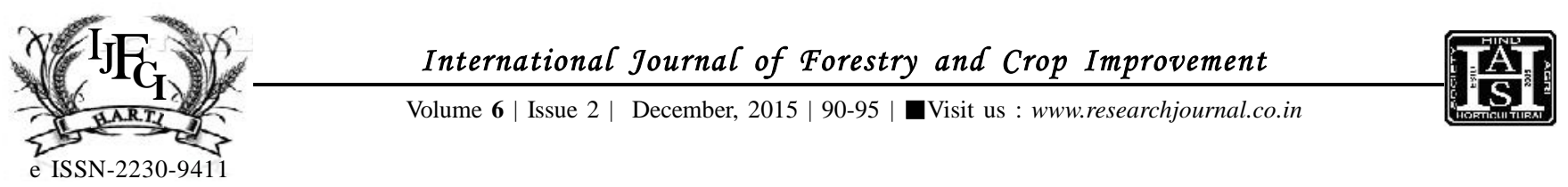

RESEARCH ARTICLE

DOI: $10.15740 / \mathrm{HAS} / \mathrm{IJFCI} / 6.2 / 90-95$

\title{
Fodder production potential of pearl millet cultivars under marginal environments of Gujarat
}

\author{
K.K. DHEDHI, V.V. ANSODARIYA, N.N. ChaUdHARIAND J.S. SORATHIYA
}

\begin{abstract}
Field experiments were carried out at Pearl millet Research Station, Junagadh Agricultural University (JAU), Jamnagar and Grassland Research Station, JAU, Dhari during Kharif 2014, to know the performance of 17 cultivars of fodder pearl millet under marginal environments of Gujarat. Significant differences were observed among the cultivars for days to 50 per cent flowering, days to maturity, grain yield and green fodder yield while differences for plant height, plant population and dry fodder yield were non-significant. The locations differences were found significant for all the characters except days to 50 per cent flowering and days to maturity. The cultivars $\mathrm{x}$ locations differences were reflected non-significant for all the traits except plant height and plant population. Days to 50 per cent flowering ranged from 55 days (IP 20611) to 78 days (IP 14753). Days to maturity varied between 84 days (DFMH 30) to 100 days (IP 14294, IP 19415). The cultivar IP 19415 (294 cm) was the tallest cultivar, while, IP $14753(223 \mathrm{~cm}$ ) was the shortest cultivar. Grain yield was observed between $5.34 \mathrm{q} / \mathrm{ha}$ (IP 20577) to $16.68 \mathrm{q} / \mathrm{ha}$ (check PAC 981 ). Dry fodder yield ranged from $72 \mathrm{q} / \mathrm{ha}$ (IP 20611) to $131 \mathrm{q} / \mathrm{ha}$ (IP 10437). The cultivar IP 10151 ( $238 \mathrm{q} / \mathrm{ha}$ ) produced the highest green fodder yield among all the cultivars followed by IP 20577 ( $236 \mathrm{q} / \mathrm{ha}$ ) and IP 10437 ( $234 \mathrm{q} / \mathrm{ha})$. Thus, these three cultivars viz., IP 10151, IP 20577 and IP 10437 may be considered for general cultivation under marginal environments of Gujarat.
\end{abstract}

KEY WORDS : Pearl millet, Cultivar, Green fodder yield, Gujarat

How TO CITE THIS ARTICLE : Dhedhi, K.K., Ansodariya, V.V., Chaudhari, N.N. and Sorathiya, J.S. (2015). Fodder production potential of pearl millet cultivars under marginal environments of Gujarat. Internat. J. Forestry \& Crop Improv., 6 (2) : 90-95.

ARTICle ChronicAL : Received : 14.07.2015; Revised : 03.11.2015; Accepted : 17.11.2015

MEMBERS OF RESEARCH FORUM

Address of the Correspondence : K.K. DHEDHI, Pearl Millet Research Station (J.A.U.) JAMNAGAR (GUJARAT) INDIA

Email: kkdhedhi@rediffmail.com

V.V. ANSODARIYA, Grassland Research Station (J.A.U.) DHARI (GUJARAT) INDIA

Address of the Coopted Authors : N.N. CHAUDHARI AND J.S. SORATHIYA, Pearl Millet Research Station (J.A.U.) JAMNAGAR (GUJARAT) INDIA 